\title{
Pengaruh Model Pembelajaran Cooperative Integrated Reading And Composition Berbantuan Circular Card Terhadap Keterampilan Menulis
}

\author{
Ni Putu Regina Eliantari ${ }^{*}$, MG. Rini Kristiantari², I Wayan Sujana ${ }^{3}$ \\ 123 Jurusan Pendidikan Guru Sekolah Dasar, Universitas Pendidikan Ganesha, Singaraja, Indonesia
}

\begin{abstract}
Abstrak
Penelitian ini bertujuan untuk mengetahui pengaruh model pembelajaran Cooperative Integrated Reading and Composition berbantuan Circular Card terhadap keterampilan menulis siswa kelas IV SD Gugus VI Mengwi Tahun Ajaran 2018/2019. Penelitian ini merupakan eksperimen semu dengan desain Nonequivalent Control Group Design. Populasi pada penelitian ini seluruh kelas IV SD Gugus VI Mengwi

Kata Kunci:

Cooperative Integrated

Reading and Composition, Circular Card, keterampilan menulis Tahun Ajaran 2018/2019 sebanyak 188 Siswa. Penentuan sampel pada penelitian ini menggunakan teknik random sampling, sehingga diperoleh kelas IV SD No 2 Kapal sebanyak 31 siswa sebagai kelas eksperimen dan kelas IV SD No 4 Kapal sebanyak 30 siswa sebagai kelas kontrol. Data keterampilan menulis siswa dikumpulkan dengan tes uraian. Hasil keterampilan dianalisis dengan uji-t polled varians. Rata-rata gain skor ternormalisasi keterampilan

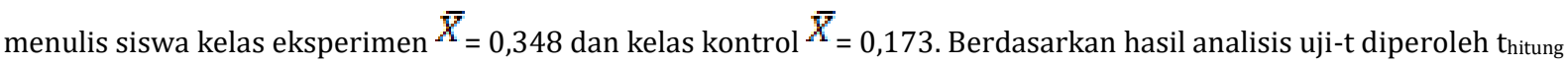
$>t_{\text {tabel }}(8,897>2,001)$ pada taraf signifikan 5\% dengan derajat kebebasan ( $\left.d \mathrm{k}=31+30-2=59\right)$ sehingga maka Ho ditolak. Hal ini menunjukkan terdapat perbedaan yang signifikan keterampilan menulis antara kelompok yang dibelajarkan menggunakan model pembelajaran Cooperative Integrated Reading and Compisition berbantuan Circular Card dan kelompok yang dibelajarkan menggunakan pembelajaran konvensional siswa kelas IV SD Gugus VI Mengwi Tahun Ajaran 2018/2019. Dengan demikian dapat disimpulkan bahwa model pembelajaran Cooperative Integrated Reading and Composition berbantuan Circular Card berpengaruh terhadap keterampilan menulis siswa kelas IV SD Gugus VI Mengwi Tahun Ajaran 2018/2019.
\end{abstract}

\section{Abstract}

This study aims to determine the effect of the Cooperative Integrated Reading and Composition learning model assisted by Circular Card on the writing skills of Grade IV Elementary School Class IV Mengwi Academic Year 2018/2019. This research is a quasi-experimental design with Nonequivalent Control Group Design. The population in this study were all fourth grade elementary school class VI Mengwi Academic Year 2018/2019 as many as 188 students. Determination of the sample in this study used a random sampling technique, so as to obtain class IV SD No. 2 Kapal as many as 31 students as the experimental class and class IV SD No. 4 Kapal as many as 30 students as the control class. Data on students' writing skills were collected by a description test. The results of the skills were analyzed by the polled variance t-test. The average gain of normalized

\section{Keywords:}

Cooperative Integrated

Reading and

Composition, circular

card, writing skills

\footnotetext{
* Corresponding author.

E-mail Addresses: - putu.regina.eliantari@undiksha.ac.id (Ni Putu Regina Eliantari)
} 
scores in the writing skills of the experimental class students $=0.348$ and the control class $=0.173$. Based on the results of the t-test analysis obtained tcount> $t$ table $(8.897>2.001)$ at a significant level of $5 \%$ with degrees of freedom $(\mathrm{dk}=31+30-2=59)$ so that Ho is rejected. This shows that there are significant differences in writing skills between the groups taught using the Cooperative Integrated Reading and Compisition-assisted Circular Card learning models and groups that are taught using conventional learning in Grade IV Elementary School class VI Mengwi Academic Year 2018/2019. Thus it can be concluded that the Cooperative Integrated Reading and Composition learning model assisted by Circular Card has an effect on the writing skills of Grade IV Elementary School class IV Mengwi Academic Year 2018/2019.

\section{PENDAHULUAN}

Dalam upaya meningkatkan mutu pendidikan diperlukan proses pembelajaran yang optimal untuk mencapai kompetensi. Uno (2011:75) menyatakan keberhasilan pencapaian kompetensi bergantung pada beberapa aspek. Salah satu aspek yang sangat mempengaruhi adalah bagaimana cara seorang guru dalam melaksanakan pembelajaran. Pembelajaran adalah sesuatu yang dilakukan oleh siswa, bukan dibuat oleh siswa. Pembelajaran merupakan upaya pendidik untuk membantu peserta didik melakukan kegiatan pembelajaran (Yudasmini, 2015).

Pendidikan merupakan kegiatan terencana yang berlangsung sepanjang hidup dan menjadi kebutuhan bagi manusia. Pendidikan tidak hanya berlangsung di sekolah, akan tetapi dapat juga berlangsung di dalam keluarga dan masyarakat. Oleh karena itu, pendidikan menjadi tanggung jawab bersama antara keluarga, masyarakat, dan juga pemerintah. Pendidikan memegang peranan penting bagi kehidupan manusia. Tanpa pendidikan manusia akan sulit berkembang atau bahkan tidak berkembang. Dengan demikian, pendidikan harus benarbenar diarahkan agar menghasilkan manusia yang berkembang dan berkualitas serta mampu bersaing, di samping memiliki akhlak dan moral yang baik.

Keberhasilan belajar peserta didik dipengaruhi oleh beberapa faktor, dapat berasal dari diri peserta didik sendiri maupun dari guru sebagai pendidik. Faktor yang berasal dari guru di antaranya kemampuan dalam merancang pembelajaran yang mampu menumbuhkan motivasi belajar peserta didik, menciptakan suasana belajar yang menarik dan menyenangkan. Namun pada kenyataannya, peserta didik masih menganggap matematika sebagai mata pelajaran yang menakutkan sehingga susah untuk dipahami. Hal ini terjadi karena pendidik belum mampu mengemas pembelajaran matematika menjadi lebih menyenangkan yang mampu menarik perhatian peserta didik. Sehingga membuat prestasi belajar peserta didik tidak sesuai dengan yang diharapkan.

Proses pembelajaran saat ini masih cenderung menempatkan guru sebagai pusat pembelajaran atau satu-satunya sumber belajar. Guru hanya sekedar memberikan pengetahuan kepada siswa. Siswa tidak diberikan kesempatan untuk membangun sendiri pengetahuan yang dimilikinya. Tentunya keadaan seperti itu berpengaruh pada hasil belajar siswa. Untuk itu perlu adanya perubahan dalam proses pembelajaran dimana dalam proses pembelajaran lebih diarahkan pada keaktifan siswa. Guru dapat memberikan kesempatan kepada siswa untuk membangun sendiri pengetahuan mereka serta guru bukan satu-satunya sebagai sumber belajar. Oleh karena itu, guru diharapkan mampu memilih model pembelajaran yang sesuai dengan materi pembelajaran agar diperoleh hasil belajar siswa yang baik (Ayuwanti, 2016).

Pendidikan itu sebenarnya harus didapatkan oleh setiap lapisan masyarakat agar pembangunan suatu bangsa dan negara itu dapat berjalan dengan baik. Hal tersebut juga terlihat dalam UUD 1945 pasal 31 yang menyatakan bahwa setiap warga negara berhak mendapatkan pendidikan (Amandemen UUD 1945, Bab XIII tentang Pendidikan dan Kebudayaan). Pernyataan dalam pasal 31 itu sekaligus merupakan landasan dan jaminan bagi setiap warga negara Indonesia untuk memperoleh pendidikan tanpa membedakan suku, agama, dan golongan.

Hasil pendidikan yang diperoleh setiap warga negara diharapkan dapat meningkatkan kualitas sumber daya manusia Indonesia secara sendiri-sendiri atau keseluruhan di masa kini dan mendatang. Sumber daya manusia Indonesia yang berkualitas tersebut memiliki ciri sebagaimana tersebut dalam tujuan pendidikan nasional yaitu: "Pendidikan nasional berfungsi mengembangkan kemampuan dan membentuk watak serta peradaban bangsa yang bermartabat dalam rangka mencerdaskan kehidupan 
bangsa, bertujuan untuk berkembangnya potensi peserta didik agar menjadi manusia yang beriman dan bertakwa kepada Tuhan Yang Maha Esa, berakhlak mulia, sehat, berilmu, cakap, kreatif, mandiri, dan menjadi warga negara yang demokratis serta bertanggung jawab.". (UUD RI Sistem Pendidikan Nasional: 2003, 2) (Sirait, 2016).

Bahasa mempunyai peranan yang sangat penting bagi kehidupan manusia. Salah satu media utama yang digunakan manusia untuk berkomunikasi adalah Bahasa Secara sederhana, bahasa dapat di artikan sebagai alat untuk berinteraksi atau alat untuk menyampaikan pikiran, gagasan, atau konsep. Sumber daya manusia yang berkompeten haruslah memiliki kemampuan untuk memproses informasi agar mampu menghadapi era globalisasi dan mengantisipasi perkembangan ilmu pengetahuan dan teknologi.

Bahasa merupakan alat komunikasi, harus dapat dengan mudah dipahami makna yang terkandung didalamnya . Keterampilan berbahasa mencakup empat aspek yaitu keterampilan menyimak, keterampilan berbicara, keterampilan membaca, dan keterampilan menulis. Menurut Tarigan (2008: 3), keterampilan menulis adalah salah satu keterampilan berbahasa yang produktif dan ekspresif yang dipergunakan untuk berkomunikasi secara tidak langsung dan tidak secara tatap muka dengan pihak lain. Keterampilan menulis dipandang perlu karena dalam kegiatan akademis siswa sering mengemban tugas untuk mengajukan pendapat atau pandangan terhadap sesuatu, misalnya memberikan argumen dalam menjawab soal-soal esai, atau dalam membuat hasil percobaan atau pengamatan. Menulis merupakan suatu kegiatan komunikasi berupa penyampaian pesan secara tertulis kepada pihak lain dengan menggunakan bahasa tulis (Dalman, 2016: 3). Menurut Tarigan (2008:22) menulis ialah menurunkan atau melukiskan lambang-lambang grafik yang menggambarkan suatu bahasa yang dipahami oleh seseorang. Menurut Susanto (2013:252) fungsi menulis adalah sebagai alat komunikasi tidak langsung karena tidak langsung berhadapan dengan pihak lain yang membaca tulisan kita tetapi menggunakan bahasa tulisan. Dengan demikian, dapat disimpulkan bahwa menulis memiliki fungsi yaitu, alat komunikasi yang dilakukan secara tidak langsung yang dituangkan menggunakan bahasa tulisan. Menurut Suparno dan Yunus (2008: 3.7), tujuan yang ingin dicapai seorang penulis bermacam-macam yaitu, menjadikan pembaca ikut berpikir dan bernalar, membuat pembaca tahu tentang hal yang diberitakan, menjadikan pembaca beropini, menjadikan pembaca mengerti, membuat pembaca terpersuasi oleh isi karangan, membuat pembaca senang dengan menghayati nilai-nilai yang dikemukakan seperti nilai kebenaran, nilai agama, nilai pendidikan, nilai sosial, nilai moral, nilai kemanusiaan dan nilai estetika. Berdasarkan pendapat tersebut, dapat disimpulkan bahwa tujuan menulis adalah agar pembaca mengetahui, mengerti dan memahami nilai-nilai dalam sebuah tulisan sehingga pembaca ikut berpikir, berpendapat atau melakukan sesuatu yang berhubungan dengan isi tulisan.

Hugo Harting (dalam Tarigan, 2008:24-25) mengklasifikasikan beberapa tujuan penulisan yaitu, (1) Tujuan penugasan (assigment purpose) Tujuan penugasan ini berarti menulis tidak memiliki tujuan sama sekali. Penulis menulis karena ditugaskan, bukan atas kemauannya sendiri, (2) Tujuan altruistik (aluistric purpose). Penulis bertujuan untuk menyenangkan pembaca, dengan menghindarkan kedukaan pembaca. Penulis ingin menolong pembaca memahami, menghargai perasaan dan penalarannya, penulis ingin membuat hidup pembaca lebih mudah dan lebih menyenangkan dengan karyanya, (3) Tujuan persuasi (persuasive purpose) Tujuan penulis adalah meyakinkan pembaca akan kebenaran gagasan yang diutarakan, (4) Tujuan Informasi (informational purpose) Tujuan penulis adalah memberikan informasi atau keterangan penerangan kepada para pembaca. (5) Tujuan pernyataan diri (self-ekspresive purpose) (6)Tujuan penulis adalah menyatakan atau memperkenalkan diri kepada pembaca. (7) Tujuan kreatif (creative purpose). Tujuan penulis adalah mencapai nilai-nilai artistik dan nilai-nilai kesenian. Berdasarkan beberapa pendapat tersebut, dapat disimpulkan bahwa tujuan menulis adalah agar pembaca mengetahui, mengerti dan memahami nilai-nilai dalam sebuah tulisan sehingga pembaca ikut berpikir, berpendapat atau melakukan sesuatu yang berhubungan dengan isi tulisan.

Menulis karangan merupakan salah satu indikator yang diturunkan dari kompetensi dasar. Karangan terbagi ke dalam 5 jenis karangan, diantaranya adalah karangan deskripsi, karangan narasi, karangan eksposisi, karangan argumentasi dan karangan peruasi. Pertama, karangan deskripsi merupakan karangan yang melukiskan atau menggambarakan suatu objek atau peristiwa tertentu menggunakan kata-kata secara jelas dan terperinci sehingga si pembaca seolah-olah turut merasakan atau mengalami langsung apa yang dideskripsikan si penulisnya (Dalman, 2016: 94). Kedua, narasi adalah tulisan yang menceritakan sebuah kejadian. Narasi kebanyakan berbentuk fiksi seperti novel, cerpen, dongeng, dan sebagainya. Selain bersifat fiktif, narasi juga bersifat faktual (lebih dikenal dengan istilah recount), seperti rangkaian sejarah, hasil wawancara naratif, transkrip interogasi, dan sebagainya (Zainurrahman, 2011: 37). Ketiga, eksposisi merupakan ragam wacana yang dimaksudkan untuk menerangkan, menyampaikan, atau menguraikan sesuatu hal yang dapat memperluas atau menambah pengetahuan dan pandangan pembacanya (Suparno dan Yunus, 2008: 1.11). Keempat, karangan argumentasi merupakan karangan yang bertujuan meyakinkan atau membuktikan kepada pembaca agar 
menerima suatu kebenaran yang disampaikan oleh penulisnya, sehingga pembaca meyakini kebenaran itu (Dalman, 2016: 138). Kelima, karangan persuasi merupakan karangan yang berusaha meyakinkan seseorang agar melakukan sesuatu yang dikehendaki pembicara pada waktu sekarang atau pada waktu yang akan datang. Sifat dari karangan ini membujuk, merayu, menghimbau, dan mengajak pembaca agar tergiur, tertarik, dan menuruti kemauan penulis (Yunus, 2008: 3.27). Dari berbagai jenis karangan, dipilih satu jenis karangan untuk dijadikan fokus penelitian dengan tujuan untuk meningkatkan kemampuan menulis karangan. Jenis karangan yang dipilih adalah karangan narasi. jenis karangan narasi yang digunakan pada penelitian ini. Jenis karangan narasi tersebut adalah adalah narasi ekspositoris dan narasi sugestif.

Berdasarkan hasil observasi dan wawancara pada tanggal 29 Januari 2019 dengan guru-guru kelas IV dan kepala Gugus VI Mengwi, bahwa kurangnya minat siswa dalam menulis terutama dalam keterampilan menulis karangan. Sedikitnya variasi selama proses pembelajaran membuat anggapan siswa tentang pelajaran bahasa Indonesia terutama pada ketrampilan menulis menjadi membosankan.

Salah satu upaya menciptakan kondisi belajar yang bermakna tersebut adalah dengan menggunakan model pembelajaran Cooperative Integrated Reading and Composition (CIRC). Kurniasih dan Berlin (2017:89) menyatakan model pembelajaran CIRC merupakan model pembelajaran yang lebih cocok dan tepat diaplikasikan pada mata pelajaran bahasa Indonesia khusus pada materi membaca, menemukan ide pokok atau tema sebuah wacana atau kliping. Menurut Slavin (2008: 204) tujuan utama dari para pengembangan program CIRC terhadap menulis dan seni berbahasa adalah untuk merancang, mengimplementasikan, dan mengevaluasi pendekatan proses menulis pada pelajaran menulis dan seni berbahasa yang banyak memanfaatkan kehadiran teman satu kelas. Pembelajaran Cooperative Integrated Reading and Composition (CIRC) dari segi bahasa dapat diartikan sebagai suatu model pembelajaran kooperatif yang mengintegrasikan suatu bacaan secara menyeluruh kemudian mengimposisikannya menjadi bagian - bagian yang penting. Kelebihan model pembelajaran CIRC yaitu (a) Guru sebagai fasilitator, (b) siswa menemukan hasil secara teliti karena bekerja dalam kelompok, (c) membangkitkan motivasi siswa, (d) menumbuhkan sikap peduli sosial dan dapat menerima pendapat orang lain.

Untuk mengoptimalkan model pembelajaran Cooperative Integrated Reading and Composition (CIRC), digunakan pula bantuan Circular Card sebagai media pembelajaran, yang menarik minat siswa dalam menulis. Menurut Arsyad (2017: 4) media pembelajaran adalah komponen sumber belajar atau wahana fisik yang dapat merangsang siswa untuk belajar. Pembelajaran adalah proses komunikasi antara pembelajar, pengajar, dan bahan ajar. Dalam proses pembelajaran sangat diperlukan pemilihan media pembelajaran yang tepat agar tujuan dari pembelajaran dapat tercapai dengan maksimal. Menurut Arsyad (2017: 74) kriteria yang perlu diperhatikan dalam pemilihan media pembelajaran yang baik adalah sebagai berikut, Sesuai dengan tujuan yaitu media pembelajaran yang dipilih hendaknya mampu diselaraskan menurut kemampuan dan kebutuhan siswa dalam mendalami isi materi, (b) Praktis, Luwes, dan Bertahan yaitu simpel dan mudah dalam penggunaan, harga terjangkau dan dapat bertahan lama serta dapat digunakan secara terus menerus patut menjadi salah satu pertimbangan utama dalam memilih media pembelajaran, (c) mampu dan Terampil Menggunakan yaitu nilai dan manfaat media pembelajaran sangat ditentukan oleh bagaimana keterampilan guru menggunakan media pembelajaran tersebut,(d) Pengelompokan Sasaran yaitu kemampuan belajar masing-masing siswa dalam kelompok juga wajib diperhatikan untuk memilih mana media pembelajaran yang tepat untuk dipilih, (e) Mutu Teknis yaitu tiap produk yang dijadikan media pembelajaran tentu memiliki standar tertentu agar produk tersebut laik digunakan, jika produk tersebut belum memiliki standar khusus guru harus mampu menentukan standar untuk produk tersebut agar dapat digunakan untuk media pembelajaran. Proses pembelajaran dengan menerapkan media Circular Cards dilakukan oleh siswa. Media Circular Card adalah dua lembar kertas tebal berbentuk lingkaran dan memiliki dua buah telinga yang berfungsi sebagai pegangan. Lembar pertama dibagi menjadi 6 atau 8 bagian yang setiap bagiannya dapat dimanfaatkan untuk menampilkan gambar dengan atau tanpa kata. Lembar kedua dipotong $1 / 6$ atau $1 / 8$ untuk melihat gambar. Kemudian kedua lembar tersebut dijadikan satu dengan menusukan batang korek agar dapat melekat. Cara menggunakan media ini adalah dengan memutar bagian yang dipotong untuk melihat urutan kagiatan atau kata yang dilihat satu persatu. Media Circular Card bertujuan untuk memperkenalkan kosa kata baru untuk memantapkan pemahaman tentang bahan yang sudah diajarkan. Selain itu, media Circular Cards digunakan untuk mengembangan penguasaan kosakata pada keterampilan menulis narasi pembelajaran bahasa indonesia. Penguasaan kosakata terkait erat dengan kemampuan menulis. Penguasaan kosakata tersebut tidak dapat diartikan hanya hafal artinya saja, namun juga paham maknanya. Oleh karena itu, diperlukan penguasaan kosakata dan pemakaian kata yang sesuai dengan konteks komunikasi yang sedang berlangsung untuk dapat menyusun kata demi kata menjadi sebuah karangan. Kekeliruan atau kesalahpahaman, mengakibatkan siswa sulit memahami apa yang dibacanya, atau apa yang digunakan ketika berbicara serta menulis. 
Kajian penelitian yang relevan dijadikan sebagai rujukan atau pembanding untuk penelitian yang telah dilaksanakan. Beberapa penelitian yang relevan untuk penelitian ini adalah sebagai berikut, (a) Penelitian yang dilakukan I Gusti Ayu Dewi Chandra Prabawati (2013) dengan hasil penelitian bahwa model CIRC berbantuan media gambar berseri berpengaruh terhadap kemampuan membaca pemahaman pada siswa kelas V SD gugus IV kecamatan Rendang. Dengan hasil analisis menunjukan bahwa terdapat perbedaan yang signifikan kemampuan membaca pemahaman antara siswa yang mengikuti pembelajaran dengan model pembelajaran CIRC berbantuan media gambar berseri dan siswa yang mengikuti pembelajaran dengan model pembelajaran konvensional pada siswa kelas V di SD Gugus IV Kecamatan Rendang., (b) Penelitian yang dilakukan oleh I Gede Agus Raka Putrawan (2017) dengan hasil penelitian bahwa model pembelajaran CIRC berpengaruh terhadap literasi membaca siswa. Terdapat perbedaan yang signifikan, antara kelompok siswa yang dibelajarkan dengan model pembelajaran CIRC dan kelompok siswa yang dibelajarkan dengan model pembelajaran langsung pada siswa kelas III di SD Gugus II, Kecamatan Bangli, Kabupaten Bangli Tahun Pelajaran 2016/2017, (c) Penelitian yang dilakukan oleh Dewa Ayu Suardi Yanti (2013) dengan hasil penelitian bahwa model pembelajaran Moody dengan memanfaatkan cerita rakyat berpengaruh terhadap keterampilan menulis karangan narasi. Terdapat perbedaan yang signifikan, antara kelompok siswa yang dibelajarkan dengan model pembelajaran Moody dan kelompok siswa yang dibelajarkan dengan model pembelajaan konvensional pada siswa kelas IV SDN 1 Ubud Tahun Pelajaran 2012/2013. Sesuai dengan kajian relevan yang sudah dipaparkan, terdapat kesamaan dengan penelitian ini dalam penggunaan model pembelajaran yaitu model pembelajaran CIRC dan perbedaannya keterampilan menulis serta pada penelitian relevan tidak menggunkan berbantuan media Circular Card.

Berdasarkan uraian tersebut secara teoritis model pembelajaran Cooperative Integrated Reading and Composition berbantuan Circular card berpengaruh terhadap keterampilan menulis karangan narasi, tetapi secara empiris perlu dibuktikan menggunakan penelitian yang berjudul " "Pengaruh Model Pembelajaran Cooperative Integrated Reading and Composition Berbantuan Circular Card Terhadap Kemampuan Menulis Siswa Kelas IV SD Gugus VI Mengwi Tahun Ajaran 2018/2019".

\section{METODE PENELITIAN}

Jenis Penelitian ini dilaksanakan di SD Gugus VI Mengwi yang terdiri atas 6 sekolah dasar, yaitu SD No. 1 Kapal, SD No. 2 Kapal, SD No. 3 Kapal, SD No. 4 Kapal, SD No. 5 Kapal, dan SD No. 6 Kapal. Penelitian ini dilaksanakan pada pada siswa kelas IV SD Gugus VI Mengwi Tahun Ajaran 2018/2019. Jenis penelitian yang dilakukan dalam penelitian ini adalah penelitian kuantitatif dengan desain eksperimen yaitu quasi eksperiment. "Desain ini memiliki kelompok kontrol, tetapi tidak dapat berfungsi sepenuhnya untuk mengontrol variabel-variabel luar yang mempengaruhi pelaksanaan eksperimen" (Sugiyono, 2017:77). Hal ini dikarenakan kemampuan peneliti dalam mengamati perilaku siswa sangat terbatas terutama ketika siswa berada di luar sekolah (rumah). Desain eksperimen yang digunakan adalah "Nonequivalent control group design". Waktu penelitian dimulai dari bulan November sampai dengan bulan Mei 2019. Kegiatan yang dilakukan selama penelitian dimulai dari pengajuan judul, penyusunan proposal, revisi proposal, persiapan penelitian, pengumpulan data, analisis data, penyusunan skripsi dan ujian skripsi. Penelitian ini merupakan penelitian kuantitatif dengan jenis quasi eksperimen dipilih karena kelompok kontrol tidak sepenuhnya dapat mengontrol variable-variabel luar yang mempengaruhi pelaksanaan eksperimen (Sugiyono, 2009). Selain itu, pemilihan subjek tidak selalu dapat dilakukan secara random, melainkan harus menggunakan kelas atau kelompok subjek yang ditentukan oleh sekolah (Setyosari, 2015). Adapun rancangan desain ekdperimen semu dipilih, yaitu Nonquivalent Control Group Design. Bentuk rancangan ini dapat digambarkan sebagai berikut.

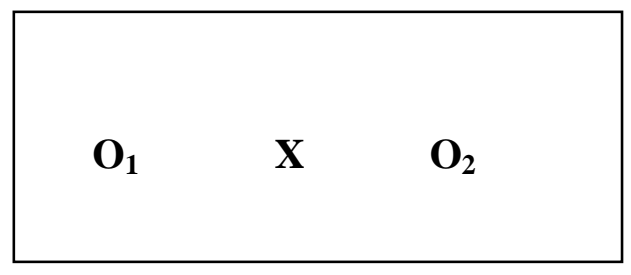

(Sumber: Sugiyono, 2017:79)

Gambar 1. Desain penelitian Nonequivalent Control Group Design 
Subjek dalam penelitian ini meliputi populasi dan sampel. Populasi dalam suatu penelitian perlu ditetapkan dengan tujuan agar penelitian yang dilakukan benar-benar mendapatkan data sesuai yang diharapkan. "Populasi adalah keseluruhan subjek penelitian" (Suharsimi Arikunto, 2014:173). menurut Sugiyono (2017:80) "populasi adalah wilayah generalisasi yang mempunyai kualitas dan karakteristik tertentu yang ditetapkan oleh peneliti untuk dicari dan kemudian ditarik kesimpulannya". Dapat disimpulkan bahwa populasi adalah keseluruhan dari subjek penelitian yang mempunyai kualitas dan karakteristik yang ditetapkan oleh peneliti. Populasi dalam penelitian ini adalah seluruh siswa kelas IV SD Gugus VI Mengwi tahun Ajaran 2018/2019, yang terdiri dari 6 sekolah dasar. Jumlah populasi dari penelitian ini adalah 188 siswa. Setelah mendata seluruh populasi penelitian, selanjutnya dilakukan penentuan sampel. "Sampel adalah sebagian atau wakil populasi yang diteliti" (Arikunto, 2014: 174). Teknik pengambilan sampel pada penelitian ini adalah simple random sampling. Menurut Sugiyono (2017:82) simple random sampling merupakan cara pengambilan sampel secara acak, sehingga setiap anggota populasi mendapatkan peluang yang sama untuk menjadi sampel penelitian. Pemilihan sampel penelitian ini tidak dilakukannya pengacakan individu melainkan hanya pengacakan kelas. Penentuan sampel dalam penelitian ini dilakukan dengan cara pengundian kelas. Nama kelas IV di semua SD populasi ditulis pada masing-masing kertas dan setiap kertas tersebut digulung dan dimasukkan ke dalam botol. Setelah itu dilakukan pengacakan dan kemudian diambil 2 gulung kertas. Nama kelas dari masing-masing SD pada gulung kertas itu merupakan sampel penelitian. Setelah menentukan sampel dari penelitian selanjutnya dilakukan pretest. Sebelum melakukan uji-t, dilakukan uji prasyarat analisis terhadap hasil pretest berupa uji normalitas sebaran data dan uji homogenitas. Uji normalitas sebaran data dengan menggunakan rumus Komlogorov-Smornov. Berdasarkan hasil undikan diperoleh kelas IV SD No. 2 Kapal sebagai kelompok kontrol dan kelas IV SD No. 4 Kapal sebagai kelompok kontrol. Metode pengumpulan data merupakan cara-cara yang digunaan untuk mengumpulkan data penelitian. Dalam penelitian ini, metode yang digunakan yaitu metode tes. Metode tes yaitu ,metode tes pengumpulan data dengan cara memberikan sejumlah tugas yang harus dikerjakan oleh peserta tes (testee) dan menghasilkan skor ( Agung, 2014). Metode tes dalam penelitian ini digunakan untuk mendapatkan data mengetahui keterampilan menulis siswa. Instrumen pengumpulan data dalam penelitian ini adalah tes subjektif. Instrumen pengumpulan data merupakan alat bantu yang dipilih untuk pengumpulan data agar lebih sistematis dan efisien (Sudaryono, 2017). Sebelum instrumen berupa tes uraian diberikan kepada kelompok sampel siswa, pembuatan kisi-kisi soal harus dipersiapkan sebagai acuan penyusunan soal. Selanjutnya penyusunan soal disesuaikan dengan kisi-kisi yang sudah dibuat dengan menelaah tiap soal oleh ahli (judgement). Penilaian hasil tes menggunakan rubrik penilian keterampilan menulis karangan narasi dan lembar penilaian karangan narasi.

Prosedur yang dilaksanakan dalam eksperimen ini terdiri dari tiga tahapan yaitu, tahap persiapan, tahap pelaksanaan, dan tahap akhir eksperimen. (1) Tahapan persiapan penelitian ini, kegitan yang dilakukan oleh peneliti, yaitu. Melakukan wawancara dan observasi dengan guru wali kelas IV di masing-masing SD Gugus VI Mengwi Tahun Ajaran 2018/2019, Membuat intrumen penelitian berupa tes uraian mengenai menulis karangan narasi, Mengkonsultasikan intrusmen penelitian pre test dan post test bersama wali kelas dan dosen pembimbing, Melakukan pengundian untuk menentukan kelompok eksperimen dan kelompok kontrol, Memberikan pre test untuk mendapatkan hasil, Menyusun RPP (Rencana Pelaksanaan Pembelajaran) bersama wali kelas (2) Tahapan pelaksanaan penilaian, kegiatan yang dilakukan oleh peneliti, yaitu Memberikan perlakuan pada kelas eksperimen berupa model pembelajaran CIR berbantuan Circular Card, Memberikan perlakuan pada kelas kontrol berupa pembelajaran konvensional, Perlakuan diberikan sebanyak 6 kali di kelas eksperimen dan 6 kali di kelas kontrol. Jumlah perlakuan yang diberikan disesuaikan dengan jam pelajaran terkait materi penelitian ini yang telah diatur dalam kurikulum dan silabus, Memberikan post test pada akhir penelitian, baik untuk kelompok eksperimen maupun kelompok kontrol, (3) Tahapan persiapan penelitian ini, kegitan yang dilakukan oleh peneliti, yaitu Menganalisi data hasil penelitian, Melakukan uji hipotesis. 
Salah satu faktor yang dapat mempengaruhi hasil penelitian adalah validitas internal. "Validitas internal menyangkut tingkat kualitas ketepatan pengendalian aspek fisik-psikologis pelaksanaan penelitian dan pemilihan atau penggunaan berbagai instrumen dalam pelaksanaan suatu penelitian" (Dantes, 2012:88). "Validitas internal bersumber dari pelaksanaan penelitian itu sendiri yang berkaitan dengan perlakuan yang diberikan apakah benar-benar menyebabkan hasil yang diobservasi dalam penelitian" Setyosari (2015). Jadi, validitas internal adalah validitas yang berkaitan dengan kontrol yang dilakukan terhadap berbagai variabel lain yang dapat mempengaruhi hasil eksperimen. Validitas internal dalam penelitian ini dapat berupa sejarah, kematangan, pengaruh penggunaan instrumen, mortalitas, dan seleksi kelompok. Berikut dijelaskan cara mengontrol ancaman terhadap hasil eksperimen berdasarkan faktor-faktor yang dapat mempengaruhi validnya penelitian ini.

\section{1) Sejarah}

Sejarah atau pengalaman kelas eksperimen dan kelas kontrol sama-sama pernah atau sedang melakukan pembelajaran tematik kurikulum 2013. "Istilah sejarah merujuk pada peristiwa yang terjadi di sekitar atau lingkungan pada saat yang sama ketika variabel eksperimental tersebut dilakukan pengujian" (Setyosari, 2015:180). Sehingga hasil penelitian ini tetap memiliki validitas historis yang tinggi.

\section{2) Kematangan atau Maturasi}

Setiap yang hidup pasti mengalami perkembangan. Perkembangan sebagai perubahan jasmani dan rohani manusia menuju ke arah yang lebih maju dan sempurna. "Kematangan merujuk pada proses perubahan yang terjadi dalam diri subjek yang dijadikan kelompok eksperimen" (Setyosari, 2015:183). Kematangan ini merupakan proses yang dialami subjek seiring dengan berjalannya waktu seperti peserta didik memperhatikan guru dalam periode waktu yang lama. Untuk mengatasi hal seperti ini peneliti melakukan penelitian dengan menggunakan periode waktu yang sama dalam penelitian untuk kelas eksperimen dan kelas kontrol sehingga memiliki kesamaan pengalaman kematangan. Periode waktu yang digunakan adalah sebanyak 6 (enam) kali pertemuan untuk melakukan perlakuan pada kelas eksperimen dan kontrol. Sehingga validitas ini tetap mempunyai validitas kematangan yang tinggi.

\section{3) Pengaruh Penggunaan Instrumen}

Instrumen ini merujuk pada suatu kenyataan bahwa perbedaan yang diobservasi dalam suatu variabel terikat dapat terjadi pada perlakuan itu sendiri. "Instrumentasi (instrumentation) adalah pengukuran atau prosedur observasi yang dipakai selama pelaksanaan perlakuan" (Setyosari, 2015:186). Prosedur ini misalnya, dilakukan dengan cara tes. Untuk mengatasi hal tersebut, maka instrumen penelitian (post test) yang digunakan dan cara pengukuran instrumen pada kelas eksperimen dan kelas kontrol adalah sama. Instrumen yang digunakan pada kelas eksperimen dan kelas kontrol yakni berupa tes uraian (essay).

\section{4) Mortalitas}

Hasil eksperimen dapat dipengaruhi oleh faktor mortalitas. "Mortalitas ini merujuk pada perbedaan hasil atau unjuk kerja setelah adanya suatu perlakuan tertentu yang mungkin terjadi, karena perubahan-perubahan komposisi kelompok bukannya hasil perlakuan itu sendiri" (Setyosari, 2015:188). Hal yang mungkin terjadi adalah peserta didik sering tidak hadir secara konsisten atau terus menerus karena suatu alasan tertentu. Hal yang demikian dapat mempengaruhi komposisi kelompok dan hasil atau skor rata-rata yang diperoleh kelompok tersebut. Cara yang dapat dilakukan yaitu dengan tidak mengikut sertakan nilai peserta didik tersebut dalam penelitian. Sehinggga sampel pada kelas eksperimen maupun kontrol dikurangi sebanyak peserta didik yang di mortal. Hal ini menyebabkan jumlah kelompok pada kelas eksperimen dan kontrol tetap sama.

\section{5) Seleksi Kelompok}

Dalam rancangan penelitian eksperimen, pertimbangan memilih subjek sangat penting, dan menjadi syarat utama dilakukannya penelitian. Diupayakan dalam penelitian yang melibatkan kelas eksperimen dan kontrol harus setara atau sama. Hasilnya adalah karena faktor perlakuan, bukan karena faktor perbedaan kelompok subjek. Cara yang dapat dilakukan untuk mengatasi hal tersebut yaitu dengan memberikan pre test kepada kedua kelompok yang menjadi sampel penelitian untuk menguji kesetaraan kelompok tersebut. Setelah sampel dinyatakan setara, barulah diberikan perlakuan. Hal ini menyebabkan 
hasil yang diperoleh pada penelitian benar-benar karena perlakuan yang diberikan, bukan karena kelas eksperimen dan kontrol memiliki kemampuan yang berbeda.

Selain faktor internal, faktor lain yang mempengaruhi hasil penelitian adalah faktor yang bersifat eksternal. Validitas eksternal mengacu pada sejauh mana suatu hasil penelitian dapat digeneralisasikan. Dengan kata lain, "validitas eksternal menyangkut tingkat (kualitas) kerepresentatifan hasil penelitian digeneralisasikan pada populasinya" (Dantes, 2012:87). "Validitas eksternal merujuk pada generalisasi dan berkenaan dengan seberapa jauh kita dapat menggeneralisasi hasil penelitian di luar latar penelitian" (Setyosari, 2015:192). Berdasarkan kedua pendapat tersebut, dapat disimpulkan bahwa validitas eksternal berkaitan dengan seberapa jauh hasil penelitian dapat digeneralisasi pada populasi. Setyosari (2015) menyatakan pada validitas eksternal juga terdapat beberapa ancaman yang meliputi interaksi antara perlakuan dan waktu. Cara mengontrol validitas eksternal adalah dengan melakukan pengamatan dan wawancara yang menyatakan bahwa tidak ada orang-orang dan latar tertentu maupun peristiwaperistiwa historis yang dapat menghambat generalisasi hasil penelitian. Faktor eksternal yang dapat mempengaruhi validitas eksternal salah satunya adalah guru.

Data yang terkumpul dalam pelaksanaan penelitian ini perlu untuk dianalisis. Teknik analisis yang digunakan untuk menganalisis data hasil penelitian adalah teknik analisis statistik inferensial. Analisis statistik inferensial yang digunakan dalam penelitian ini adalah uji t ( $t$-test). Uji-t dapat digunakan apabila data yang terkumpul sudah memenuhi uji prasyarat analisis, yaitu uji normalitas sebaran data dan uji homogenitas varians (Agung, 2016). Dalam penelitian ini, uji normalitas sebaran data ditentukan dengan menggunakan rumus Komlogorov-Smornov dan uji homogenitas varians menggunakan uji F. jika sudah memenuhi prasyarat analisis yaitu uji normalatas sebaran data dan uji homogenitas varians, maka data selanjutnya dianalisis dengan statistik parametrik. Analisis statistic yang digunakan untuk menguji hipotesis penelitian ini menggunakan uji-t dengan polled varians.

\section{ANALISIS DAN PEMBAHASAN}

Data yang dideskripsikan pada hasil penelitian ini adalah hasil tes keterampilan menulis siswa kelas IV pada kelompok eksperimen dan kelompok kontrol. Setelah dilakukan pengundian sampel yang setara, keseluruhan siswa kelas IV Sd No. 2 Kapal ditetapkan sebagai kelas Eksperimen dan keseluruhan siswa kelas IV SD No. 4 Kapal ditetapkan sebagai kelas kontrol. Kelas kontrol dibelajarkan secara konvensional sebanyak 6 kali, sedangkan pada kelas eksperimen diberi perlakuan berupa model pembelajaran Cooperative Integrated Reading and Composition (CIRC) berbantuan Circular Card sebanyak 6 kali. Data hasil keterampilan menulis siswa diperoleh dari hasil posttest yang diberikan pada akhir penelitian. Instrumen yang digunakan untuk mengumpulkan data adalah tes esai. Deskripsi data hasil keterampilan menulis siswa yang dipaparkan meliputi nilai rerata, standar deviasi, dan varians. Berdasarkan hasil analisis keterampilan menulis nilai rata-rata 0.348, standar deviasi 0.068 dan Variansi 0.005 . sedangkan nilai rata-rata siswa kelompok kontrol 0.173 , standar deviasi 0.084 dan variansi 0.007 . Uji prsyarat dalam penelitian dilakukan sebagai syarat dipergunakannya statistik parametrik seperti pengujian hipotetsis dengan menggunakan uji-t. uji prasyarat tersebut terdiri dari uji normalitas sebaran data dan uji homogenitas varians. Uji normalitas sebaran data dilakukan untuk mengetahui sebaran frekuensi skor. Uji normalitas dalam penelitian ini dilakukan dengan menggunakan rumus KomlogorovSmornov. Kriteria pengujian pada taraf siginifikansi 5\% jika A1 atau A2 < harga kritis KomlogorovSmornov, maka $\mathrm{H}_{0}$ diterima. Berdasarkan hasil uji normalitas kelompok eksperimen, diperoleh nilai maksimum 0.191 dan nilai tabel Komlogorov-Smornov $=0.238$, karena nilai maksimum $=0.191<$ nilai tabel Komlogorov-Smornov $=0.238$, maka data berdistribusi normal. Perhitungan uji normalitas kelompok kontrol diperoleh nilai maksimum $=0.136$ dan nilai tabel Komlogorov-Smornov $=0.242$, karena nilai maksimum $=0.136<$ nilai Komlogorov-Smornov $=0.242$, maka data berdistribusi normal .

Uji homogenitas varians dilakukan untuk menunjukkan bahwa dua atau lebih kelompok data sampel berasal dari populasi yang memiliki varians yang sama sehingga perbedaan yang terjadi dalam uji hipotesis benar-benar terjadi akibat adanya perbedaan antara kelompok, bukan akibat dari adanya perbedaan dalam kelompok (Agung, 2014). Uji homogenitas varians dalam penelitian ini menggunakan uji F. Berdasarkan hasil uji homogenitas varians, diperoleh $F_{\text {hitung }}$ 1.59. Nilai tersebut kemudian dibandingkan dengan $\mathrm{F}_{\text {tabel }}$ pada taraf signifikansi 5\% dengan derajat kebebasan pembilang $=31-1=30$ dan derajat kebebasan penyebut $=30-1=29,\left(F_{\text {tabel }}=1,85\right)$, sehingga didapat hasil $F_{\text {hitung }}<F_{\text {tabel }}(1.59<1,85)$ yang berarti data homogen. Berdasarkan hasil uji prasyarat yang terdiri dari uji normalitas sebaran data dan uji homogenitas varians, disimpulkan bahwa data kedua kelompok sampel ialah berdistribusi normal dan memiliki varians yang homogen. Dengan demikian, uji hipotesis menggunakan uji-t dapat dilakukan. Hipotesis yang diuji dalam penelitian ini adalah tidak terdapat pengaruh model pembelajaran Cooperative Integrated Reading and Composition (CIRC) berbantuan Circular card terdahap keterampilan menulis 
siswa kelas IV SD Gugus VI Mengwi Tahun Ajaran 2018/2019. Hasil uji prasyarat yang meliputi uji normalitas sebaran data dan uji homogenitas varians menunjukkan bahwa data kedua kelompok sampel ialah berdistribusi normal dan memiliki varians yang homogen, sehingga dapat menggunakan analisis statistik parametrik. Analisis statistik parametrik yang digunakan yaitu uji-t dengan polled varians. Berdasarkan hasil uji-t, diperoleh $t_{\text {hitung }}=8.897$. Nilai tersebut kemudian dibandingkan dengan $t_{\text {tabel }}$ pada taraf signifikansi 5\% dengan derajat kebebasan $=59\left(t_{\text {tabel }}=2,001\right)$, dan didapat hasil $t_{\text {hitung }}>t_{\text {tabel }}$ (8.897>2,000) sehingga Ho ditolak, Berikut disajikan rekapitulasi hasil analisis data dengan menggunakan uji t pada Tabel 1 .

Tabel 1. Rekapitulasi analisis uji-t.

\begin{tabular}{|c|c|c|c|c|c|c|}
\hline Nama Sekolah & & & $t_{\text {hitung }}$ & $\mathrm{Dk}$ & $t_{\text {tabel }}$ & Keterangan \\
\hline -Kelompok Eksperimen & & & 8.897 & 59 & 2,001 & $\mathrm{H}_{0}$ Ditolak \\
\hline $\begin{array}{l}\text { (Kelas IV SD No. } \\
\text {-Kelompok Kontrol } \\
\text { (Kelas IV SD No. } 4 \text { Kapal) }\end{array}$ & 2 & Kapal) & & & & \\
\hline
\end{tabular}

Berdasarkan hasil uji-t, diperoleh $t_{\text {hitung }}=8.897$. Nilai tersebut kemudian dibandingkan dengan $t_{\text {tabel }}$ pada taraf signifikansi $5 \%$ dengan derajat kebebasan $=59\left(t_{\text {tabel }}=2,001\right)$, dan didapat hasil $t_{\text {hitung }}>t_{\text {tabel }}$ (8.897>2,000) sehingga Ho ditolak, yang berarti terdapat perbedaan yang signifikan keterampilan menulis antara kelompok siswa yang dibelajarkan dengan model pembelajaran Cooperative Integrated Reading and Composition (CIRC) berbantuan Circular Card dan kelompok siswa yang dibelajarkan dengan pembelajaran konvensional. Dengan demikian disimpulkan bahwa terdapat pengaruh model pembelajaran Cooperative Integrated Reading and Composition (CIRC) berbantuan Circular Card terhadap keterampilan menulis siswa kelas IV SD Gugus VI Mengwi Tahun Ajaran 2018/2019. Rata-rata keterampilan menulis siswa kelompok yang dibelajarka dengan model pembelajaran Cooperative Integrated Reading and Composition (CIRC) berbantuan Circular Card rakyat yaitu 0.348. sedangkan keterampilan menulis siswa kelompok kontrol yang dibelajarkan dengan pembelajaran konvensional yaitu 0.173. Namun, dilihat perolehan nilai rata-rata, kelompok eksperimen memiliki rata-rata lebih tinggi daripada kelompok kontrol. Hal ini berarti model pembelajaran Cooperative Integrated Reading and Composition (CIRC) memiliki pengaruh yang lebih baik terhadap keterampilan menulis siswa dilihat dari perolehan nilai rata-rata antara kelompok eksperimen dan kelompok kontrol.

Pada kelompok eksperimen, kegiatan pembelajaran dalam menggunakan model pembelajaran Cooperative Integrated Reading and Composition (CIRC) berbantuan Circular Card berlangsung dengan kondusif dan menyenangkan. Siswa menjadi aktif dan bersemangat dalam pembelajaran karena pembelajaran dengan model pembelajaran Cooperative Integrated Reading and Composition (CIRC) berbantuan Circular Card difokuskan pada permasalahan yang dialami oleh kebanyakan siswa. Berbantuan dengan Circular Card siswa mampu menambah wawasan mengenai arti dari setiap kosa kata yang sulit. Selain itu dalam pembelajaran model pembelajaran Cooperative Integrated Reading and Composition (CIRC) berbantuan Circular Card siswa mampu bekerjasama dengan kelompok dalam memecahkan masalah yang ditemukan serta mengemukakan pendapat mengenai cara pemecahan masalah tersebut. Dari berbagai kegiatan yang dilakukan selama pembelajaran, terlihat bahwa siswa memiliki minat dan motivasi yang tinggi untuk mengikuti pembelajaran dengan baik. Dalam kelompok kontrol, kegiatan pembelajaran dilakukan secara konvensional sehingga pembelajaran berlangsung kurang bermakna untuk siswa. Hal ini mengakibatkan kurangnya kesempatan siswa untuk melatih keterampilan menulis siswa. Selain itu kurangnya penggunaan media pembelajaran mengakibatkan materi yang disampaikan guru kurang dipahami oleh siswa, akibatnya, siswa sulit memahami materi yang disampaikan dan merasa cepat bosan. Kegiatan pembelajaran menggunakan model pembelajaran Cooperative Integrated Reading and Composition (CIRC) berbantuan Circular Card memberikan pengaruh terhadap kemampuan membaca pemahaman siswa kearah yang lebih baik karena model pembelajaran Cooperative Integrated Reading and Composition (CIRC) berbantuan Circular Card memiliki kelebihan dalam kegiatan pembelajaran dengan mengajak siswa untuk aktif dalam memecahkan masalah tersebut, sehingga pembelajaran menjadi bermakna untuk siswa. Penggunaan bantuan Circular Card dalam pembelajaran memberi pengalaman belajar yang lebih beragam kepada siswa.

Dengan demikian pembelajaran menggunakan model Cooperative Integrated Reading and Composition (CIRC) berbantuan Circular Card pada penelitian ini memiliki keunggulan yaitu untuk melatih kemampuan keterampilan menulis dalam merangkai wawancara menjadi karangan. Hasil temuan pada 
penelitian ini memiliki persamaan dengan penelitian sebelumnya yang relevan dan memperkuat hasil penelitian yang diperoleh, yaitu penelitian yang dilakukan hal tersebut didukung oleh I Gusti Ayu Dewi Chandra Prabawati (2013) dengan hasil penelitian bahwa model CIRC berbantuan media gambar berseri berpengaruh terhadap kemampuan membaca pemahaman pada siswa kelas V SD gugus IV kecamatan Rendang dan penelitian yang dilakukan oleh I Gede Agus Raka Putrawan (2017) dengan hasil penelitian bahwa model pembelajaran CIRC berpengaruh terhadap literasi membaca siswa.

\section{KESIMPULAN}

Berdasarkan hasil analisis data penelitian dan pembahasan nilai rata-rata keterampilan menulis siswa yang dibelajarkan menggunakan model pembelajaran Cooperative Integrated Reading and Compesition berbantuan Circular Card dan kelompok siswa yang dibelajarkan menggunakan pembelajaran konvensional pada siswa kelas IV SD Gugus VI Mengwi Tahun Ajaran 2018/2019. Hal ini terbukti dari analisis uji-t diperoleh $t_{\text {hitung }}=8.897$ dan $t_{\text {tabel }}=2.001$ pada taraf signifikan $5 \%$ dengan derajat kebebasan $(\mathrm{dk}=31+30-2=59)$ Karena $t_{\text {hitung }}>\mathrm{t}_{\text {tabel }}(8.897>2.001)$ maka Ho ditolak dan Ha diterima. Sehingga, dapat disimpulkan bahwa model pembelajaran Cooperative Integrated Reading and Compesition berbantuan Circular Card berpengaruh terhadap keterampilan menulis siswa kelas IV SD Gugus VI Mengwi Tahun Ajaran 2018/2019.

Adapun saran yang dapat disampaikan setelah dilaksanakan dan diperoleh hasil dari penelitian ini yaitu : (1) Kepada Guru, Berdasarkan temuan penelitian yang diperoleh, dapat dijadikan acuan dalam pemilihan model pembelajaran yang sesuai dengan Kurikulum 2013 dengan melihat karakteristik muatan pembelajaran yang terintegrasi, pendekatan saintifik serta kebutuhan siswa. Kegiatan pembelajaran pun menjadi lebih inovatif dan variatif karena dapat menggunakan model pembelajaran yang sesuai dengan Kurikulum 2013. Salah satu model pembelajaran yang dapat disarankan, yaitu Cooperative Integrated Reading and Compesition berbantuan Circular Card terutama pada keterampilan menulis siswa. (2) Kepada Siswa, Dengan dilakukannya penelitian ini, siswa siswa diharapkan mampu menjadi aktif, berfikir kritis, bertanggung jawab, dan membentuk interaksi yang positif antar siswa dalam mengikuti proses pembelajaran serta mampu meningkatkan 4 keterampilan yang optimal, khususnya pada keterampilan menulis. (3) Kepada Kepala Sekolah, berdasarkan hasil penelitian ini, disarankan kepada kepala sekolah agar dapat menggunakan hasil penelitian ini sebagai pendukung sumber belajar guru dalam meningkatkan kualitas pembelajaran yang sesuai dengan karakteristik Kurikulum 2013. (4) kepada peneliti lain, agar hasil penelitian ini digunakan sebagai referensi untuk melaksanakan penelitian selanjutnya atau menemukan inovasi kegiatan pembelajaran lainnya yang bermakna bagi siswa sesuai dengan Kurikulum 2013 agar dapat memotivasi siswa untuk mengikuti kegiatan pembelajaran dengan baik.

\section{DAFTAR PUSTAKA}

Agung, A. A. Gede. 2014. Statistik Dasar untuk Pendidikan.Yogyakarta: $\quad$ Deepublish.

Arikunto, Suharsimi. 2014. Prosedur Penelitian (Suatu Pendekatan Praktik). Jakarta: Rineka Cipta.

Arsyad, Azhar. 2017. Media Pembelajaran. Jakarta: PT Raja Grafindo Persada.

Ayuwanti, Irma . 2016. Meningkatkan Aktivitas Dan Hasil Belajar Matematika Menggunakan Model Pembelajaran Kooperatif Tipe Group Investigation Di Smk Tuma'ninah Yasin Metro . Jurnal SAP Vol. 1 No. 2 Desember 2016.

Dalman. 2016. Keterampilan Menulis. Jakarta: PT. Raja Grafindo Persada.

Kurniasih dan Berlin. 2017. Ragam Pengembangan Model Pembelajaran Untuk Peningkatan Profesionalitas Guru: Kata Pena.

Sirait, Erlando Doni . Pengaruh Minat Belajar Terhadap Prestasi Belajar Matematika . Jurnal Formatif 6(1): 35-43, 2016.

Slavin, Robert E. 2008. Cooperative Learning Teori, Riset dan Praktik. Terjemahan Narulita Yusron. Cooperative Learning: theory, research and practice. Bandung: Penerbit Nusa Media. 
Sudaryono.2017.Metodologi Penelitian.Jakarta: PT Raja Grafindo Persada.

Sugiyono.2017.Metode penelitian (Pendekatan Kuantitatif, Kualitatif, dan R\&D). Bandung: Alfabeta

Susanto, Ahmad. 2013. Teori Belajar dan Pembelajaran di Sekolah Dasar. Jakarta: Kencana Prenadamedia Group.

Tarigan, Henry Guntur. 2008. Menulis Sebagai Suatu Keterampilan Berbahasa. Bandung: CV Angkasa.

Tarigan, Henry Guntur. 2011. Menulis Sebagai Suatu Keterampilan Berbahasa. Bandung: CV Angkasa.

Yudasmini, Ni M. 2015. Pengaruh Model Pembelajaran Circ (Cooperative Integrated Reading And Composition) Terhadap Minat Baca Dan Kemampuan Memahami Bacaan Pada Siswa Kelas Vi Di Sekolah Dasar Gugus Buruan . e-Journal Program Pascasarjana Universitas Pendidikan Ganesha Program Studi Penelitian dan Evaluasi Pendidikan (Volume 5, No 1 Tahun 2015). 